\title{
Pendidikan Kesehatan dengan Pendekatan Model Information Motivation Behavior Skill (IMB) terhadap Peningkatan Pengetahuan dan Pola Konsumsi Sayur dan Buah pada Ibu Hamil
}

\author{
Farhati $^{1}$, Riska Resmana ${ }^{2}$, Dian Nurhadianti ${ }^{3}$ \\ Jurusan Kebidanan, Politeknik Kesehatan Kemenkes Bandung, Indonesia \\ Email: f4rh4t1@gmail.com
}

\begin{abstract}
Health Education by Modeling the Information Motivation Behavioral Skill (IMB) on Increasing Knowledge and Consumption Patterns of Vegetables and Fruits in Pregnant Women. Low consumption of vegetables and fruit causes an increased risk of chronic diseases such as cancer, heart disease, and diabetes. The results showed that the majority of pregnant women $(52,9 \%)$ rarely consume vegetables and fruit in sufficient quantities as recommended. Therefore, it is necessary to provide education about the importance of vegetables and fruits consumption, one of which is through the Information Motivation Behavioral Skill (IMB) approach. This study aims to determine the effect of health education with the Information Motivation Behavior Skill (IMB) approach to increasing knowledge and consumption patterns of vegetables and fruits in pregnant women. This research is a quasi-experimental study with pre-post test design with control groups conducted in pregnant women in the city of Bandung with 60 samples using the observation sheet and questionnaire instruments. Data analysis used the chisquare test. The result of this study indicates that there are significant differences in knowledge and patterns of consumption of vegetables and fruit in pregnant women between the control and treatment groups with a p-value<0,05. Information Motivation Behavior Skill (IMB) Health Education Model approach has a role in increasing the knowledge and consumption patterns of vegetables and fruits in pregnant women.
\end{abstract}

Keywords: Information motivation behavior skill (IMB) model, Knowledge, Pregnant mother

\begin{abstract}
Abstrak: Pendidikan Kesehatan dengan Pendekatan Model Information Motivation Behavior Skill (IMB) terhadap Peningkatan Pengetahuan dan Pola Konsumsi Sayur dan Buah pada Ibu Hamil. Rendahnya konsumsi sayur dan buah berkaitan dengan meningkatnya risiko terjadinya penyakit-penyakit kronik seperti penyakit kanker, jantung dan diabetes. Hasil riset menunjukkan bahwa sebagian besar ibu hamil (52,9\%) jarang mengonsumsi sayur dan buah dalam jumlah yang cukup sesuai anjuran. Oleh karena itu perlu diberikan edukasi tentang pentingnya konsumsi sayuran dan buah salah satunya melalui pendekatan Information Motivation Behavioral Skill (IMB) model. Penelitian ini bertujuan mengetahui pengaruh pendidikan kesehatan dengan pendekatan Information Motivation Behavior Skill (IMB) Model terhadap peningkatan pengetahuan dan pola konsumsi sayur dan buah pada ibu hamil. Desain penelitian quasi eksperimen pre-post test design with control groups yang dilakukan pada ibu hamil di wilayah Kota Bandung dengan subjek 60 sampel menggunakan instrumen lembar observasi dan kuesioner. Analisis data menggunakan uji chi square. Hasil penelitian ini ditemukan bahwa pengetahuan dan pola konsumsi sayur dan buah pada ibu hamil antara kelompok kontrol dan perlakuan terdapat perbedaan yang bermakna dengan nilai $p$-value $<0,05$. Pendidikan kesehatan dengan pendekatan Model Information Motivation Behavior Skill (IMB) berperan meningkatkan pengetahuan dan pola konsumsi sayur dan buah pada ibu hamil ibu hamil.
\end{abstract}

Kata kunci: Information motivation behavior skill (IMB) Model, Pengetahuan, Ibu hamil

\section{PENDAHULUAN}

Konsumsi sayur dan buah sangat penting untuk memenuhi kebutuhan zat gizi mikro bagi tubuh. Sayur dan buah adalah sumber makanan yang kaya vitamin dan mineral yang dibutuhkan untuk pertumbuhan, perkembangan, dan fungsi normal tubuh manusia (Almatsier, 2010). Buah dan sayuran mengandung banyak serat makanan baik serat larut maupun tidak larut yang penting untuk fungsi optimal saluran pencernaan. (Slavin JL, 2008) Disamping itu vitamin dan mineral yang terkandung dalam sayur dan buah juga berperan dalam proses metabolisme zat gizi lain 
seperti karbohidrat dan lemak sebagai sumber energi (Park S, 2005).

Masalah gizi dapat terjadi pada seluruh kelompok umur, bahkan masalah gizi pada suatu kelompok umur tertentu akan mempengaruhi status gizi pada periode siklus kehidupan berikutnya (intergenerational impact). Perubahan paradigma menuju pada pemahaman bahwa untuk hidup sehat tubuh tidak saja memerlukan protein dan kalori, tetapi juga vitamin dan mineral yang banyak terkandung dalam sayursayuran dan buah-buahan dengan pola konsumsi gizi seimbang (Kementerian Kesehatan, 2014).

Masa kehamilan merupakan periode khusus dimana ibu tidak hanya memenuhi kebutuhan energi dan zat gizi untuk dirinya sendiri melainkan juga kebutuhan janin. Selama hamil, tubuh wanita mengalami banyak perubahan baik fisik, mood, maupun hormonal, yang berdampak terhadap munculnya berbagai keluhan dan masalah selama kehamilan. Kurangnya konsumsi sayuran dan buah pada ibu hamil berdampak terhadap berbagai gangguan seperti konstipasi, anemia, meningkatnya risiko terjadinya kanker, serta penyakit- penyakit kronik lainnya seperti jantung dan diabetes.

Insiden penyakit tidak menular dan kronis seperti kanker, diabetes mellitus, dan penyakit kardiovaskular juga meningkat di negara berkembang, sebagian besar dipengaruhi oleh perubahan gaya hidup dan pola makan. Faktor gaya hidup termasuk pola makan telah mengalami perubahan yang drastis dalam beberapa dekade terakhir, sebagai dampak dari pergeseran global, urbanisasi, industrialisasi, dan perkembangan teknologi. (Popkin, 2006; Maiyaki, 2014).

Organisasi Kesehatan Dunia (WHO) menyarankan mengkonsumsi lebih dari 400gr buah dan sayuran per hari (setara dengan lima porsi) untuk meningkatkan kesehatan secara keseluruhan dan mengurangi risiko penyakit tidak menular tertentu (WHO, 2003).

Pemenuhan gizi yang baik dan seimbang pada ibu hamil dapat mengoptimalkan pertumbuhan dan perkembangan janin, terhindar dari resiko komplikasi kehamilan dan kelainan atau cacat pada janin. Oleh karena itu, memperhatikan asupan makanan dan juga nutrisi sangat penting dilakukan oleh ibu hamil. Tubuh tidak hanya memerlukan protein dan kalori saja, tetapi juga memerlukan asupan vitamin, mineral dan serat yang banyak terkandung dalam sayursayuran dan buah-buahan. Konsumsi sayur dan buah yang cukup dapat mengurangi keluhan konstipasi (sembelit) dan anemia pada ibu hamil (Wibisono, 2009; Ojieh, 2012)
Pemenuhan gizi yang baik dan seimbang pada ibu hamil dapat mengoptimalkan pertumbuhan dan perkembangan janin, terhindar dari resiko komplikasi kehamilan dan kelainan atau cacat pada janin. Oleh karena itu, memperhatikan asupan makanan dan juga nutrisi sangat penting dilakukan oleh ibu hamil. Tubuh tidak hanya memerlukan protein dan kalori saja, tetapi juga memerlukan asupan vitamin, mineral dan serat yang banyak terkandung dalam sayursayuran dan buah-buahan (Wibisono, 2009; Ojieh, 2012).

Berdasarkan data Riskesdas tahun 2013 secara nasional terlihat bahwa proporsi rata-rata Rumah Tangga (RT) yang mengkonsumsi sayur dan buah hanya $10,7 \%$ dan prevalensi nasional kurang makan sayur dan buah pada penduduk umur $>10$ tahun ialah 93,5\% (Balitbangkes, 2013). Penelitian Wahyuni tentang pola konsumsi sayur dan buah serta asupan serat dan micronutrient pada ibu hamil di Kabupaten Gowa pada tahun 2013 menunjukkan bahwa frekuensi konsumsi buah dan sayur pada ibu hamil termasuk dalam kategori kurang. Hal ini terlihat pada proporsi ibu hamil yang sering mengkonsumsi buah dan sayur hanya $45,5 \%$. Senada dengan penelitian Febriana dan Sulaiman pada tahun 2014 di Beji, Kota Depok ditemukan bahwa sebagian ibu jarang mengonsumsi sayur dan buah $(52.9 \%)$. Hal ini menunjukkan bahwa kesadaran ibu untuk mengonsumsi sayur dan buah selama kehamilan masih perlu ditingkatkan.

Strategi untuk meningkatkan pola konsumsi sayur dan buah pada ibu hamil adalah dengan memberikan pendidikan kesehatan yang dapat meningkatkan pengetahuan, motivasi dan perilaku dalam mengkonsumsi sayur dan buah. Salah satunya adalah metode pendidikan kesehatan yang dirancang dengan pendekatan Information Motivation Behavioral Skill (IMB) model (Fisher, 2003).

Model IMB menjelaskan bagaimana membentuk perilaku sehat melalui informasi, motivasi dan perubahan perilaku pada pasien (Amico KR, et al., 2005). Beberapa penelitian menunjukkan keefektifan penerapan model ini pada upaya mencegah perilaku beresiko HIV, keselamatan berkendara, memperbaiki pola diit pasien dengan diabetes mellitus secara mandiri, kepatuhan pemeriksaan payudara sendiri, dan kepatuhan dalam mengkonsumsi obat Anti Retroviral (ARV) bagi pasien HIV (Amico KR et a.l, 2005; Diclmete RJ, et al., 2002;) Namun belum ada penelitian sebelumnya yang menggunakan model ini pada perilaku perbaikan pola konsumsi sayur dan buah. 
Pendidikan kesehatan berdasarkan model IMB ini berbeda dengan pendidikan konvensional yang hanya berdasarkan ceramah. Pendidikan kesehatan dengan model IMB disesuaikan dengan teori perubahan perilaku, sehingga diharapkan dapat meningkatkan pengetahuan, motivasi dan perilaku ibu hamil melalui pemberian informasi, resiko dan dampak kurangnya asupan sayur dan buah pada ibu hamil, serta cara pengolahan sayur dan buah yang baik dan benar.

Berdasarkan latar belakang tersebut, untuk meningkatkan pengetahuan dan perilaku konsumsi sayur dan buah diperlukan modul pendidikan kesehatan salah satunya dengan pendekatan Information Motivation Behavior Skill (IMB) Model yang dapat dijadikan sebagai alternative dalam mengatasi masalah kurangnya tingkat konsumsi sayur dan buah pada ibu hamil.

\section{METODE}

Penelitian ini merupakan penelitian kuantitatif dengan rancangan quasi eksperimen menggunakan pendekatan control group with pre and post-test design. Pengambilan sampel menggunakan metode quota sampling. Subjek penelitian ini adalah seluruh ibu hamil di wilayah Puskesmas Garuda dan Puskesmas Ibrahim Adji Kota Bandung yang dibagi menjadi 2 kelompok, kelompok perlakuan yaitu ibu hamil yang memeriksakan diri ke Puskesmas Garuda dan kelompok kontrol adalah ibu hamil yang memeriksakan diri di Puskesmas Ibrahim Adji. Subjek penelitian berjumlah 60 orang dengan kriteria inklusi yaitu ibu hamil trimester II dan III serta bersedia menjadi responden, sedangkan kriteria eksklusi adalah ibu hamil yang tidak bisa baca tulis. Instrumen yang digunakan berupa kuesioner dan lembar observasi. Uji validitas dan reliabilitas kuesioner menggunakan pemodelan Rasch.

Subjek diminta mengisi kuesioner dan lembar observasi pola konsumsi sayur dan buah selama 1 minggu ke depan sebagai pre test. Setelah 1 minggu, dilakukan pertemuan kembali, kelompok perlakuan diberikan pendidikan kesehatan dengan model Information Motivation Behavior Skill (IMB), sedangkan kelompok kontrol diberikan penyuluhan dengan metode konvensional ceramah. Kemudian subjek pada kedua kelompok diminta untuk mengisi kuesioner post test dan pola konsumsi sayur dan buah selama 1 minggu berikutnya. Analisis bivariat dalam penelitian ini menggunakan uji statistik chi square dengan menggunakan $\alpha$ sebesar 0,05 .

Penelitian ini telah mendapat persetujuan etik penelitian dari Komisi Etik Penelitian Kesehatan Politeknik Kesehatan Kemenkes Bandung Nomor: 16/KEPK/PE/VI/2018.

\section{HASIL}

Tabel 1. Kesetaraan Karakteristik Subjek Kelompok Perlakuan dan Kontrol

\begin{tabular}{|c|c|c|c|}
\hline $\begin{array}{c}\text { Karakteristik } \\
\text { Subjek } \\
\text { Penelitian }\end{array}$ & $\begin{array}{c}\text { Perlakuan } \\
\mathbf{n}=\mathbf{3 0}\end{array}$ & $\begin{array}{c}\text { Kontrol } \\
\mathbf{n}=\mathbf{3 0}\end{array}$ & $\begin{array}{c}\text { Nilai } \\
p- \\
\text { value }\end{array}$ \\
\hline \multicolumn{4}{|l|}{ Usia (Tahun) } \\
\hline - $\quad \operatorname{Mean}(\mathrm{SD})$ & $29,03(5,7)$ & $29,8(6,8)$ & 1.000 \\
\hline - Median & 29,50 & 28 & \\
\hline - Range & 20 & 26 & \\
\hline \multicolumn{4}{|l|}{ Pendidikan } \\
\hline - Dasar & 1 & 3 & 0,516 \\
\hline - Menengah & 22 & 24 & \\
\hline - Perguruan & 7 & 3 & \\
\hline Tinggi & & & \\
\hline \multicolumn{4}{|l|}{ Skor } \\
\hline \multicolumn{4}{|l|}{ pengetahuan } \\
\hline - $\quad \operatorname{Mean}(\mathrm{SD})$ & 75 & 70 & \\
\hline - Median & 45 & 40 & \\
\hline - Range & & & \\
\hline \multicolumn{4}{|l|}{ Pola Konsumsi } \\
\hline \multicolumn{4}{|l|}{ sayur buah pre } \\
\hline - $\quad \operatorname{Mean}(\mathrm{SD})$ & $3,20(1,2)$ & $3(1,2)$ & 0,478 \\
\hline - Median & 3 & 3 & \\
\hline - Range & 4 & 4 & \\
\hline
\end{tabular}

Berdasarkan hasil analisis perbandingan kedua kelompok subjek penelitian pada tabel diatas menunjukkan bahwa kedua kelompok setara, terlihat dari karakteristik usia, tingkat pendidikan, skor awal pengetahuan dan pola konsumsi mempunyai nilai $p$-value $>0,05$ yang menunjukkan bahwa kedua kelompok subyek penelitian tidak ada perbedaan yang bermakna sehingga layak untuk diperbandingkan.

Tabel 2. Perbedaan Pengetahuan Pre dan Post-Test pada Kelompok Perlakuan dan Kelompok Kontrol

\begin{tabular}{lcccc}
\hline Pengetahuan & $\begin{array}{c}\text { Min- } \\
\text { Max }\end{array}$ & $\begin{array}{c}\text { Mean } \pm \\
\text { SD }\end{array}$ & $\begin{array}{c}\text { Selisih } \\
\text { rerata } \pm \text { SD }\end{array}$ & $\begin{array}{c}\text { Nilai } \\
\boldsymbol{p} \text { - } \\
\text { value }\end{array}$ \\
\hline $\begin{array}{l}\text { Perlakuan } \\
\text { Pre-test }\end{array}$ & $45-90$ & $72 \pm 10,9$ & $14,3 \pm 9,16$ & 0,000 \\
Post-test & $70-100$ & $86,3 \pm(8,4)$ & & \\
\hline
\end{tabular}

Analisis perbedaan tingkat pengetahuan pada kedua kelompok dilakukan dengan membandingkan skor hasil penilaian pre dan post test seperti tercantum pada tabel.

Pada tabel 2 diketahui bahwa skor pengetahuan pre-test antara kelompok perlakuan 
dan kontrol, tidak terdapat perbedaan bermakna ( $p$-value $>0.05)$, dan terdapat perbedaan yang bermakna pada skor pengetahuan post-test antara kelompok perlakuan dan kelompok kontrol, serta peningkatan skor pengetahuan pre dan post-test pada kelompok kontrol dan perlakuan dengan nilai $p$-value $<0.05$.

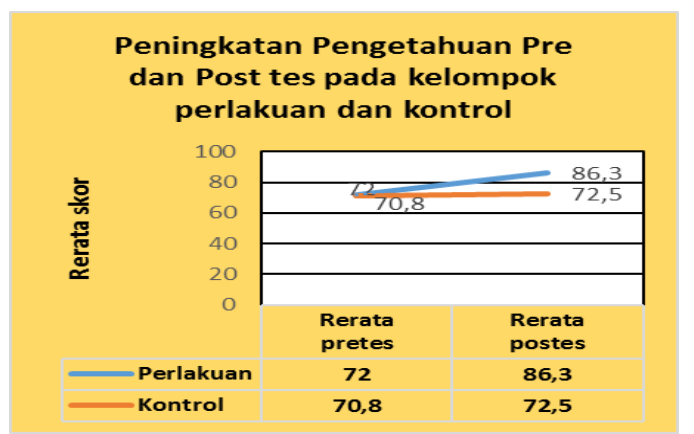

Grafik 1. Peningkatan Skor Pengetahuan pre dan post-test pada Kelompok Perlakuan dan Kontrol

Peningkatan skor pengetahuan pre dan post-test pada kelompok kontrol dan perlakuan akan disajikan dengan grafik 1 yang menunjukkan bahwa terdapat peningkatan rerata skor pengetahuan pada kelompok perlakuan sebesar 14,3 poin. Sementara skor pengetahuan pada kelompok kontrol hanya terjadi peningkatan sebesar 1,6 poin.

\begin{tabular}{|c|c|c|c|c|c|}
\hline \multirow[t]{2}{*}{ Tabel 3.} & \multicolumn{2}{|c|}{$\begin{array}{l}\text { Perbedaan } \\
\text { Pengetahuan } P \\
\text { Kelompok }\end{array}$} & $\begin{array}{l}\text { ategori } \\
\text { Test an }\end{array}$ & $\begin{array}{r}T i \\
\operatorname{tara} K\end{array}$ & $\begin{array}{l}\text { igkat } \\
\text { edua }\end{array}$ \\
\hline & & huan & & Nilai & \\
\hline Kelompok & $\begin{array}{c}\begin{array}{c}\text { Kurang } \\
\text { baik }\end{array} \\
\end{array}$ & Baik & Total & $\begin{array}{c}p- \\
\text { value }\end{array}$ & $\begin{array}{c}\text { (IK } \\
\mathbf{9 5 \%})\end{array}$ \\
\hline $\begin{array}{l}\text { Kontrol } \\
(\mathrm{n}=30)\end{array}$ & $\begin{array}{r}22 \\
(73,3 \%) \\
\end{array}$ & $\begin{array}{r}8 \\
(26,7 \%) \\
\end{array}$ & $\begin{array}{r}30 \\
(100 \%) \\
\end{array}$ & 0.000 & $\begin{array}{r}4,4 \\
(1.8-\end{array}$ \\
\hline $\begin{array}{l}\text { Perlakuan } \\
(\mathrm{n}=30)\end{array}$ & $\begin{array}{r}5 \\
(16.6 \%)\end{array}$ & $\begin{array}{r}25 \\
(83,3 \%)\end{array}$ & $\begin{array}{r}30 \\
(100 \%)\end{array}$ & & $9,2)$ \\
\hline
\end{tabular}

Pada tabel 3 dapat diketahui bahwa dari 60 subjek penelitian yang diteliti, kelompok yang mendapatkan perlakuan sebagian besar $(83,3 \%)$ memiliki tingkat pengetahuan dengan kategori baik, sedangkan pada kelompok kontrol sebagian besar $(73,3 \%)$ memiliki tingkat pengetahuan kurang baik. Terdapat perbedaan tingkat pengetahuan antara kelompok kontrol dan perlakuan dengan nilai $p$-value $<0,05$ dan RR: 4,4 .
Tabel 4. Perbedaan Pola Konsumsi Sayur dan Buah Pre dan Post Test pada Kelompok Perlakuan dan Kelompok Kontrol

\begin{tabular}{lrrrr}
\multicolumn{1}{c}{ Pola } & $\begin{array}{c}\text { Min } \\
\text { Konsumsi }\end{array}$ & $\begin{array}{c}\text { Median } \pm \text { SD } \\
\text { Max }\end{array}$ & $\begin{array}{c}\text { Selisih } \\
\text { median } \pm S D\end{array}$ & $\begin{array}{c}\text { Nilai } \\
\boldsymbol{p} \text { - } \\
\text { value }\end{array}$ \\
\hline Perlakuan & & & & \\
$\begin{array}{l}\text { Pre-test } \\
\text { Post-test }\end{array}$ & $1-5$ & $3 \pm 1,2$ & $1 \pm 0,7$ & 0.001 \\
\hline Kontrol & $2-5$ & $4 \pm 0,9$ & & \\
$\begin{array}{l}\text { Pre-test } \\
\text { Post-test }\end{array}$ & $1-5$ & $3 \pm 1,2$ & $0 \pm 0,3$ & 0,478 \\
\hline
\end{tabular}

Tabel 4 menunjukkan bahwa tidak terdapat perbedaan bermakna pada pola konsumsi pre-test antara kelompok perlakuan ( -value $>0,05)$. Terdapat perbedaan yang bermakna pada pola konsumsi post test antara kelompok perlakuan dan kelompok kontrol, serta pola konsumsi antara pre dan post test pada kelompok perlakuan serta peningkatan pola konsumsi pre dan post-test pada kelompok kontrol dan perlakuan dengan nilai $p$-value $<0,05$.

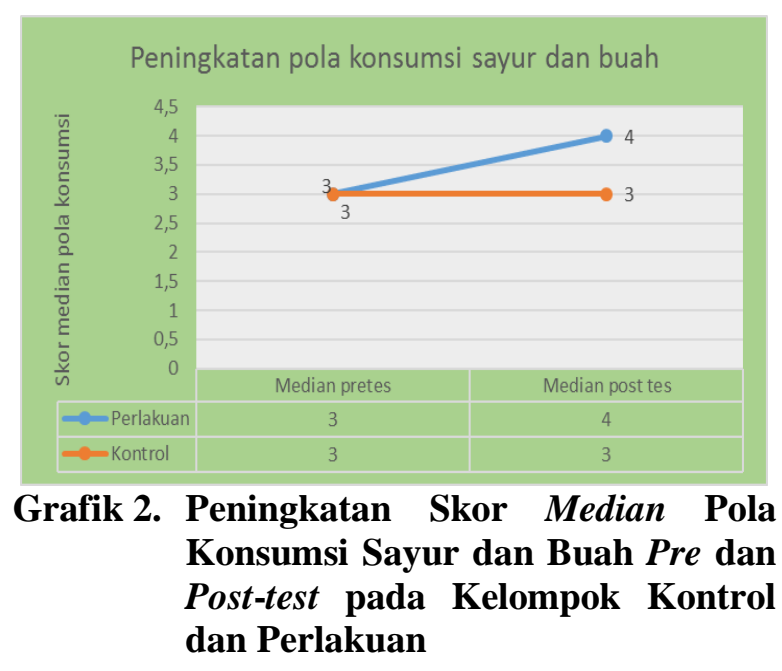

Grafik 2 menunjukkan bahwa terdapat peningkatan skor median pola konsumsi pada kelompok perlakuan setelah mendapatkan pendidikan kesehatan dengan pendekatan Model IMB sebesar 1 poin. Sementara skor pola konsumsi pada kelompok kontrol tidak terjadi peningkatan yang bermakna.

\section{PEMBAHASAN}

Perbedaan Tingkat Pengetahuan pada Kelompok Kontrol dan Perlakuan

Tingkat pengetahuan pada kedua kelompok setelah mendapat perlakuan terdapat perbedaan yang signifikan, hal ini dapat dilihat pada tabel 2 dimana terdapat perbedaan 
pengetahuan antara kelompok perlakuan dengan kontrol dengan nilai $(p$-value $<0,05)$. Pada grafik 1 menunjukkan peningkatan rerata skor pengetahuan pada kelompok perlakuan sebesar 14,3 poin, dan tingkat pengetahuan pada kelompok kontrol hanya terjadi peningkatan sebesar 1,6 poin.

Pendidikan kesehatan dengan pendekatan Model Information Motivation Behavior (IMB) ini dirancang untuk meningkatkan pengetahuan dan pola konsumsi sayur dan buah pada ibu hamil berdasarkan kajian teori dan penelitian yang menyebutkan faktor determinan kesehatan adalah informasi, motivasi dan ketrampilan perilaku. Dalam model ini dapat dijelaskan bahwa seseorang akan berperilaku secara rasional berdasarkan informasi yang diperoleh. Informasi dan motivasi dapat mempengaruhi perilaku secara langsung. Motivasi termasuk pada sikap dan kepercayaan tentang ketrampilan dan perilaku seseorang (Fisher, 2003).

Dalam pengembangan perilaku kesehatan berdasarkan model IMB ada 3 ranah dalam proses perubahan perilaku, yaitu informasi, motivasi dan ketrampilan perilaku. Informasi dalam model IMB menjelaskan bahwa informasi merupakan hal yang paling penting dan berpengaruh terhadap kemampuan berperilaku yang sehat dalam hal ini adalah perilaku konsumsi sayur dan buah.

Dalam penelitian ini informasi yang disampaikan terkait dengan permasalahan kesehatan ibu hamil tentang asupan sayur dan buah seperti jenis-jenis serat makanan, sumber serat makanan, kebutuhan asupan sayur dan buah bagi ibu hamil, dampak kurangnya asupan sayur dan buah pada ibu hamil, cara pengolahan sayur dan buah yang benar. Informasi yang relevan dapat meningkatkan pengetahuan bagi ibu. Ibu hamil juga diberikan motivasi dengan menekankan pada nilai manfaat, resiko serta kemudahan dalam memperoleh sayur dan buah, keterjangkauan dari segi ekonomi sehingga mendorong ibu dalam meningkatkan konsumsi sayur dan buah. Selain itu ibu hamil juga diajarkan cara pengolahan sayur dan buah yang benar sehingga kandungan zat gizi didalamnya tidak rusak dan dapat memenuhi angka kecukupan kebutuhan asupan sayur dan buah bagi ibu hamil.

Pendidikan gizi sebagai pendekatan edukatif
untuk menghasilkan individu/masyarakat yang diperlukan dalam peningkatan atau dalam mempertahankan gizi tetap baik. Pertimbangan domain pengetahuan gizi menunjukkan bahwa pola konsumsi sayur dan buah cenderung terkait dengan tujuan dan sudut pandang konsumen. Sebuah studi literatur menunjukkan bahwa pengetahuan gizi mungkin berpengaruh kecil tetapi berperan penting dalam perubahan perilaku atau mengadopsi kebiasaan mengkonsumsi makanan sehat termasuk sayur dan buah (Worsley, 2002).

Pengetahuan merupakan ranah yang sangat penting untuk terbentuknya perilaku seseorang. Pengetahuan seseorang terhadap objek mempunyai intensitas atau tingkatan yang berbeda-beda (Notoatmodjo, 2012). Pengetahuan gizi adalah salah faktor yang berpengaruh terhadap perubahan perilaku konsumsi makanan, pengetahuan yang baik diperlukan tetapi tidak cukup untuk merubah perilaku konsumsi makanan sehat sesuai dengan anjuran. Banyak faktor yang berpengaruh terhadap perilaku konsumsi sayur dan buah, sejumlah faktor lingkungan dan individu, termasuk niat, persepsi dan motivasi. Interaksi antara faktor-faktor tersebut dan pemrosesan informasi adalah penting untuk menghasilkan sebuah perilaku yang diharapkan.

Penelitian Dhaneswara (2016) menyatakan bahwa pengetahuan berhubungan dengan sikap seseorang dalam mengonsumsi sayur dan buah. Begitu pula dengan penelitian yang dilakukan oleh Mulyani, dkk. (2014) yang menyatakan bahwa adanya hubungan antara pengetahuan dengan perilaku gizi seimbang. Menurut Notoadmodjo (2012) bahwa pengetahuan atau ranah kognitif merupakan domain yang sangat penting dalam membentuk tindakan seseorang (overt behavior), maka dapat dikatakan dengan berpengatahuan baik tentang sayur dan buah maka konsumsinya juga akan baik. Pendidikan gizi yang dilakukan oleh Owais, et al. (2017) selama 2 tahun dapat meningkatkan kualitas diet pada balita di Bangladesh. Penelitian Reinbott, et al. (2016) membuktikan bahwa pendidikan gizi selama 1 tahun dapat meningkatkan konsumsi makanan kaya akan beta karoten serta sayur dan buah.

Pada dasarnya pendidikan kesehatan melalui ceramah juga berpengaruh meningkatkan pengetahuan seseorang. Namun pendidikan kesehatan menggunakan booklet dengan pendekatan model IMB terbukti lebih efektif dalam meningkatkan pengetahuan.

\section{Perbedaan Pola Konsumsi Sayur dan Buah pada Ibu Hamil}

Pola konsumsi sayur dan buah pada kedua kelompok terdapat perbedaan yang signifikan, hal ini dapat dilihat pada tabel 4 dimana terdapat perbedaan pola konsumsi antara kelompok yang 
diberikan pendidikan kesehatan dengan pendekatan model IMB dan metode konvensional dengan nilai ( $p$-value<0,05). Pada grafik 2 menunjukkan peningkatan skor median pola konsumsi pada kelompok perlakuan sebesar 1 poin. Sementara pola konsumsi pada kelompok kontrol tidak terjadi peningkatan.

Hasil ini sejalan dengan beberapa penelitian yang menunjukkan keefektifan penerapan model IMB dalam upaya memperbaiki pola diit pasien dengan diabetes mellitus secara mandiri, mencegah perilaku beresiko HIV, keselamatan berkendara, kepatuhan pemeriksaan payudara sendiri, dan kepatuhan dalam mengkonsumsi obat Anti Retroviral (ARV) bagi pasien HIV (Amico KR, et al., 2005; Diclmete RJ, et al., 2002; Osborn CY, et al., 2010)

Pendidikan kesehatan melalui pendekatan Model Information Motivation Behavior (IMB) dapat digunakan untuk membuat konsep penentu perilaku konsumsi sayur dan buah pada ibu hamil. Berdasarkan Model IMB, ibu hamil harus dipandu secara sederhana untuk memahami sendiri tentang kebenaran perilaku kesehatan. Hasil penelitian ini konsisten dengan hasil penelitian Osborn CY., et al (2010) yang menyebutkan bahwa penerapan Model IMB dalam memperbaiki pola diit pasien diabetes mellitus secara mandiri dapat meningkatkan pengetahuan tentang diabetes, lebih termotivasi untuk mengatur pola diit dan memiliki lebih banyak motivasi sosial.

Penelitian lain yang dilakukan oleh Stephanie et al (2012) menyebutkan bahwa intervensi yang menggabungkan pengembangan keterampilan kognitif-perilaku dapat menjadi faktor kunci untuk mempromosikan aktivitas fisik serta asupan buah dan sayuran pada remaja. Menurut Amico, et al (2005), keterampilan berperilaku merupakan kemampuan individu untuk melakukan tindakan pencegahan, memastikan bahwa seseorang mempunyai keterampilan alat dan strategi untuk berperilaku yang didasarkan pada keyakinan (self efficacy) dan perasaan bahwa ia dapat mempengaruhi keadaan/situasi (preceived behavioral control) untuk melakukan perilaku tersebut. Keterampilan berperilaku merupakan prasyarat yang menentukan apakah informasi dan motivasi yang bagus mampu mendorong tindakan pencegahan atau perubahan perilaku yang efektif.

Pola makan merupakan perilaku paling penting yang dapat mempengaruhi keadaan gizi individu. Hal ini disebabkan karena kuantitas dan kualitas makanan dan minuman yang dikonsumsi akan berpengaruh terhadap asupan zat-zat gizi sehingga akan mempengaruhi kesehatan individu dan masyarakat (Kementerian Kesehatan RI, 2014).

Kekurangan konsumsi sayur dan buah sebagai sumber serat, vitamin dan mineral dapat memicu terjadinya obesitas dan kejadian penyakit tidak menular seperti penyakit jantung dan pembuluh darah, kanker kolon, diabetes, hipertensi dan stroke (Joanne, 2012). Konsumsi sayuran dan buah-buahan yang cukup, merupakan salah satu indikator sederhana dari pola makan sehat dengan gizi seimbang. (Kementerian Kesehatan RI, 2014)

Diet ibu selama kehamilan berpengaruh terhadap kesehatan ibu dan janin (Knudsen, 2008; Okubo, 2012; Brantsæter, 2014). Pola makan nabati yang mengandung beragam buah dan sayuran terkait dengan penurunan risiko kelainan kongenital (Vujkovic, et al., 2009) kelahiran prematur (Brantsæter, et al., 2014), dan pertumbuhan janin yang lebih menguntungkan (Rao, et al., 2001) serta mengurangi resiko komplikasi pada ibu seperti kenaikan berat badan kehamilan yang berlebihan (Brantsæter, et al., 2014), preeklampsia (Hillesund, et al., 2014) dan diabetes gestasional (Trygvadottir, et al., 2016).

Meskipun masa kehamilan dipandang sebagai waktu dimana wanita lebih termotivasi berubah menuju gaya hidup positif, namun sebuah penelitian kualitatif di Australia melaporkan bahwa proporsi wanita hamil yang menganggap kehamilan sebagai periode yang sulit untuk merubah gaya hidup menjadi lebih sehat lebih tinggi dibandingkan dengan menganggap lebih mudah. Faktor komplikasi kehamilan seperti mual, kelelahan dan mengidam menjadi hambatan (Sui, et al., 2013). Studi yang lain menunjukkan bahwa tingkat konsumsi sayur dan buah meskipun ketika sedang musim (tersedia dengan harga yang lebih murah), konsumsi buah- buahan dan sayuran tetap masih rendah (Banwat, et al., 2012).

Banyak faktor yang dapat mempengaruhi konsumsi buah dan sayur pada ibu hamil, faktor tersebut antara lain adalah faktor internal dan faktor eksternal. Sejumlah penelitian menunjukkan bahwa konsumsi sayuran dan buah di pengaruhi oleh preferensi, pendidikan, kelompok sosial, jumlah anggota keluarga, jenis pekerjaan dan juga tingkat pendapatan rumah tangga (Hanani, dkk., 2016). Pola diet pra kehamilan juga sangat berpengaruh terhadap pola konsumsi sayur dan buah selama kehamilan (Skreden, et al., 2017).

Pengetahuan bukan merupakan satusatunya komponen yang berpengaruh terhadap perilaku konsumsi sayur dan buah, beberapa faktor lain yang berpengaruh adalah: (1) 
Konsekuensi yang dirasakan dari perilaku; (2) Sikap dan keyakinan tentang perilaku dan objek perilaku; (3) Keterampilan seperti mengetahui cara mengolah makanan adalah penting; (4) Keyakinan atau self efficacy untuk bisa melakukan perilaku tersebut; (5) Lingkungan sosial dan fisik, internal dan eksternal; (6) Motivasi atau pengaruh sosial sangat penting. (Worsley, 2002).

Hasil uji statistik menunjukkan beda ratarata nilai pengetahuan antara pre-test dan posttest pada kelompok kontrol dan intervensi menunjukkan perbedaan yang signifikan. Jika dilihat dari selisih nilai rata-rata, kelompok perlakuan relative lebih tinggi dibandingkan dengan selisih peningkatan nilai rerata pada kelompok kontrol. Hal ini menunjukkan bahwa ada pengaruh positif dan signifikan dari pendidikan kesehatan dengan pendekatan model

\section{DAFTAR PUSTAKA}

Almatsier. (2010). Prinsip Dasar Ilmu Gizi. Jakarta: Gramedia Pustaka.

Amico KR, Toro-Alfonso J, Fisher JD. (2005). An empirical test of the information, motivation and behavioral skills model of antiretroviral therapy adherence. AIDS Care. 2005 Aug;17(6):661-73

Balitbang Kemenkes RI. 2013. Riset Kesehatan Dasar; RISKESDAS. Jakarta: Balitbang Kemenkes RI

Banwat ME, Lar LA, Daboer J, Audu S, Lassa S. Knowledge and intake of fruit and vegetables consumption among adults in an urban community in North central Nigeria. Niger Health J, 2012;12:1.

Brantsæter, A. L., Haugen, M., Myhre, R., Sengpiel, V., Englund-Ögge, L., Nilsen, R. M., ... \& Von Ruesten, A. (2014). Diet matters, particularly in pregnancy-Results from $\mathrm{MoBa}$ studies of maternal diet and pregnancy outcomes.

Dhaneswara, D.P. (2016). Perilaku makan sayur dan buah pada mahasiswa asrama Universitas Airlangga berdasarkan theory of planned behavior. [Skripsi]. Surabaya: Universitas Airlangga.

Diclmete RJ, Crosby RA \& Kegler MC. (2002). Emerging Theories In Health Promotion Practice and Research. San Fransisco: Jossey Bass Willey Company.

Febriana R dan Sulaeman A. (2014). Kebiasaan Makan Sayur Dan Buah Ibu Saat Kehamilan Kaitannya Dengan Konsumsi
IMB terhadap peningkatan pengetahuan dan pola konsumsi sayur dan buah.

\section{SIMPULAN}

Ada perbedaan peningkatan pengetahuan dan pola konsumsi sayur dan buah pada ibu hamil sebelum dan sesudah diberikan intervensi pendidikan kesehatan dengan pendekatan Model IMB. Terdapat perbedaan peningkatan pengetahuan dan pola konsumsi sayur dan buah antara kelompok perlakuan dan kelompok kontrol. Pendidikan kesehatan dengan pendekatan Model "Information-MotivationBehavioral Skill" (IMB) terbukti efektif dalam meningkatkan pengetahuan dan pola konsumsi sayur dan buah pada ibu hamil.

Sayur Dan Buah Anak Usia Prasekolah. $J G P$, Volume 9, Nomor 2, Juli 2014.

Fisher, W. A., Fisher, J. D., \& Harman, J. (2003). The Information-Motivation-Behavioral Skills model: A general social psychological approach to understanding and promoting health behavior. In J. Suls \& K. A. Wallston (Eds.), Social psychological foundations of health and illness (pp. 82-106).Malden,MA: Blackwell.

Hanani, Z., Suyatno, S., \& Pradigdo, S. F. (2016). Faktor-faktor Yang Mempengaruhi Konsumsi Sayur Dan Buah Pada Ibu Hamil Di Indonesia (Berdasarkan Data Riskesdas 2013) the Affecting Factors of Vegetables and Fruit Consumption on Indonesian Pregnant Women (Based on Indonesia Basic Health Research 2013). Jurnal Kesehatan Masyarakat (eJournal), 4(1), 257-266.

Hillesund ER, Overby NC, Engel SM, Klungsoyr $\mathrm{K}$, Harmon QE, Haugen M, Bere $\mathrm{E}$. (2014). Associations of adherence to the New Nordic Diet with risk of preeclampsia and preterm delivery in the Norwegian Mother and Child Cohort Study (MoBa). Eur J Epidemiol. 2014;29(10):753-765.

Joanne L. Slavin and Beate Lloyd. (2012). Health Benefits of Fruits and Vegetables. American Society for Nutrition. Adv. Nutr. 3: 506-516, 2012; doi:10.3945/ an.112.002154.2012 
Kementerian Kesehatan RI. (2014). Pedoman Gizi Seimbang. Jakarta: Kementerian Kesehatan RI.

Knudsen VK, Orozova-Bekkevold IM, Mikkelsen TB, Wolff S, Olsen SF. (2008). Major dietary patterns in pregnancy and fetal growth. Eur $J$ Clin Nutr. 2008;62(4):463-70.

Maiyaki MB, Garbati MA. (2014). The burden of non-communicable diseases in Nigeria; in the context of globalization. Ann Afr Med, 2014;13:1-10.

Mulyani, E.Y., Mustikawati, I.S., Handayani, P., Rumana, N.A. (2014). Pengetahuan, sikap, dan perilaku gizi seimbang anak sekolah dasar di SDN GU 12 Pagi. Jurnal Abdimas, 1(1), 98-104. Diakses dari ejurnal.esaunggul.ac.id/ index.php/ABD/ article/download/ 1196/1091.

Notoatmodjo S. Promosi Kesehatan dan Perilaku Kesehatan. (2012). Jakarta: Rineka Cipta.

Ojieh AE. (2012). Constipation In Pregnancy And The Effect Of Vegetable Consumption In Different Socio-Economic Class In Warri, Delta State. Journal of Medical And Applied Biosciences. 4: 1-6

Okubo H, Miyake Y, Sasaki S, Tanaka K, Murakami K, Hirota Y, Kanzaki H, Kitada M, Horikoshi Y, Ishiko O, et al. (2012). Maternal dietary patterns in pregnancy and fetal growth in Japan: the Osaka Maternal and Child Health Study. Br J Nutr. 107(10):1526-33.

Osborn CY, Amico KR, Fisher WA, Egede LE, Fisher JD. (2010). An Information Motivation Behavioral Skills Analysis of Diet and Exercise Behavior in Puerto Ricans with Diabetes. J Health Psychol. Nov; 15(8): 1201-1213.

Owais, A., Schwartz, B., Kleinbaum D.G., et al (2017). A nutrition education program in rural Bangladesh was associated with improved feeding practice but not with child growth. American Society for Nutrition, 147(5),948-954. Diakses dari https://www.ncbi.nlm. nih.gov/ pubmed/ 28298543.

Park S. (2005). Nutrition and Health. In: Park's Textbook of Preventive and Social Medicine. 18th ed. India: Bhanot Publishers.

Popkin B.M. (2006). Technology, transport, globalization and the nutrition transition food policy. Food Policy.

Rao S, Yajnik CS, Kanade A, Fall CH, Margetts BM, Jackson AA, Shier R, Joshi S, Rege $\mathrm{S}$, Lubree $\mathrm{H}$, et al. (2001). Intake of micronutrient-rich foods in rural Indian mothers is associated with the size of their babies at birth: Pune Maternal Nutrition Study. J Nutr. 131(4):1217-24.

Reinbott, A., Schelling, A., Kuchenbecker, J.,et al. (2016). One year nutrition education intervention improves dietary diversity but not stunting among children aged 6 to 23 months in rural Cambodia. Di dalam: Effectiveness of a Nutrition Education Intervention to Improves Complementary Feeding Practices. [Unpublished Doctor's thesis]. Germany: VVB Laufersweiler Verlag.

Skreden, et al. (2017). Changes in fruit and vegetable consumption habits from prepregnancy to early pregnancy among Norwegian women. BMC Pregnancy and Childbirth, 17:107.

Slavin JL. (2008). Position of the American dietetic association: Health implications of dietary fiber. $J \mathrm{Am}$ Diet Assoc, 108:1716-31.

Stephanie K, Bernadette MM, Michael B. (2012). Predicting Physical Activity and Fruit and Vegetable Intake in Adolescents: A Test of the Information, Motivation, Behavioral Skills Model. Research in Nursing \& Health. 35, 146-163

Sui Z, Turnbull D, Dodd J. (2013). Enablers of and barriers to making healthy change during pregnancy in overweight and obese women. Australas Med J.6(11):565-77.

Tryggvadottir EA, Medek H, Birgisdottir BE, Geirsson RT, Gunnarsdottir I. (2016). Association between healthy maternal dietary pattern and risk for gestational diabetes mellitus. Eur $J$ Clin Nutr. 70(2):237-42.

Vujkovic, M., Steegers, E. A., Looman, C. W., Ocké, M. C., van der Spek, P. J., \& Steegers-Theunissen, R. P. (2009). The maternal Mediterranean dietary pattern is associated with a reduced risk of spina bifida in the offspring. BJOG: $A n$ International Journal of Obstetrics \& Gynaecology, 116(3), 408-415.

Sriwahyuni, I. R., \& Salam, A. (2013). Pola Konsumsi Buah dan Sayur Serta Asupan Zat Gizi Mikro dan Serat pada Ibu Hamil di Kabupaten Gowa 2013. Jurnal MKMI.

Wibisono H, Dewi ABFK. (2009). Solusi Sehat Seputar Kehamilan. Jakarta: AgroMedia Pustaka.

World Health Organization. (2003). Promoting fruit and vegetable consumption around the world. Global Strategy on Diet, 
Physical Activity and Health; World Health Organization: Geneva, Switzerland. Worsley, Anthony. (2002). Nutrition knowledge and food consumption: Can Nutrition knowledge change food behaviour?. Asia Pacific J Clin Nutr. 11(Suppl): S579S585. 